\title{
Relationship between Job Stress and the Turnover Intention of Private Sector Bank Employees in Bangladesh
}

\author{
Nazrul Islam ${ }^{1}$, Ekhtear Ahmed Zeesan ${ }^{2}$, Debanik Chakraborty ${ }^{2}$, Md. Nafizur Rahman ${ }^{2}$, Syed Istiak Uddin \\ Ahmed $^{2}$, Nowshin Nower ${ }^{2}$, Toufiq Nazrul ${ }^{3}$ \\ ${ }^{1}$ Pro-Vice Chancellor, Canadian University of Bangladesh, Dhaka, Bangladesh \\ ${ }^{2}$ Bangladesh University of Professionals, Dhaka Cantonment, Dhaka, Bangladesh \\ ${ }^{3}$ University of Denver, Colorado, USA \\ Correspondence: Nazrul Islam, Pro-Vice Chancellor, Canadian University of Bangladesh, Dhaka, Bangladesh.
}

Received: June 24, 2019

doi:10.5539/ibr.v12n8p133
Accepted: July 22, $2019 \quad$ Online Published: July 29, 2019

URL: https://doi.org/10.5539/ibr.v12n8p133

\begin{abstract}
Private sector banks are important segments of the economy of Bangladesh. This sector has already been recognized as a significant industry for achieving the Sustainable Development Goals (SDG) of Bangladesh. However, managing private organizations has become very challenging due to highly competitive market and higher level of employee turnover especially in the private banking sector. It is observed that to attain the competitive advantage, private bank employees are undertaking heavy workload that leads to higher level of stress at work and is increasing turnover intention among the employees. This study has been designed to explore the factors that are accountable to create stress among the private bank employees in Bangladesh which are creating turnover intention among them. Hence, this study identified the relationships between job stress factors and the increase of turnover intensions among the bank employees in Bangladesh. A total of 206 bank employees at different levels of the banks were interviewed from ten private commercial banks of Bangladesh. A structured questionnaire was designed through literature review to collect the information from the respondent employees. Both descriptive and inferential statistics were used to analyze the data. Multivariate analysis techniques were used to identify the work stress factors having influence on the turnover intention among the private bank employees in Bangladesh. Results show that there are four stress factors that increase the turnover tension among the private bank employees in Bangladesh such as, (i) long hours and fast work, (ii) clearness of goals and objectives of work, (iii) workload and change in mindset, and (iv) flexibility at work. This study suggests that the policymakers of the private commercial banks should address the issues like long hours and fast work, clearness of goals and objectives of work, workload and change in mindset and flexibility at work for reducing turnover intensions of the bank employees in Bangladesh.
\end{abstract}

Keywords: job stress, workload, working environment, flexibility at work, turnover intention

\section{Background}

Banking sector of Bangladesh is playing a pivotal role in the economy of Bangladesh which is growing very fast in recent years. It is playing a significant role in the economic development of Bangladesh which is already recognized as a significant industry for achieving the sustainable development goals of the country. However, managing private organizations has become very challenging due to highly competitive market and higher level of employee turnover. To attain the competitive edge of the banks, private bank employees are undertaking heavy workload that leads to higher level of work stress which is reducing productivity and increasing turnover intention among the employees. It is observed that in last decade, banks have been going through enormous changes in organization and structure. New technology and new ways of structuring the operations have left their mark on the working conditions and daily lives of employees. Deregulation of labor markets, emerging technologies and new types of jobs have significantly reshaped working lives by continuous changes on employment and working conditions which is creating tensions among the employees.

Stress in the Banking sector has increased the mental health problems. Different workshops \& seminars has been arranged for the betterment of the employees since the stress factors being identified as a grave issue. Job satisfaction, job pressure \& most importantly the organizational factors (like-organizational commitment, rigidity 
in rules, sincerity \& cooperation from the organization etc.) have huge impact on the turnover intention. Although stress is a universal and common challenge of the employees at work, it is the reality of modern-days' workplace. Performance level declination, absenteeism, excessive tension even drug addiction etc. are being identified as the harmful impacts of Job Stress. So thus, by the time the importance of administration to look after employee expectation enhanced. Banking sector is undergoing rapid technological change. Many employees in the banking industry are struggling to adjust with the rapid technological change \& thus turnover intention is rising. So, banking authorities are focusing on making favorable grounds for the employees to adjust the change. Moreover, work life balance, role ambiguity etc. are also being focused on to maintaining the stress factors at a favorable level. This study will be able to identify the factors related to management behavior and the working environment of the bank employees in Bangladesh.

\section{Objectives of the Study}

The broad objective of this study is to identify the stress factors and its impact on turnover intension of the bank employees in Bangladesh. The specific objectives are as follows.

i. $\quad$ To identify the stress factors of the private sector bank employees in Bangladesh;

ii. To identify the relationships between the stress factors and the turnover intensions of the private sector bank employees in Bangladesh;

iii. To provide some suggestions which will help reducing turnover intension among the bank employees in Bangladesh?

\section{Literature Review}

The development of the relationship between job stress \& turnover intention is an evolutionary process, which developed step by step by the standards \& foundation set by various researches. Study identified (Giorgi and others, 2017) found that mental health problems has increased in the banking sector which are stress-related. Examples began with anxiety and depression, carried on through maladaptive behaviors, and ended in job burnout. Das (2016) defined stress as psychological and physiological dimensions where it derived from physics and mechanics. He found that the banking sector is one of the high stress creating sectors among the women workers. To reduce the stress level among the working women, seminars and workshops should be organized to deal with stress and women should not stay too long or unnecessarily at workplace, and they should avoid multiple tasks at a same time. The study on stress at work has revealed five dimensions of the impact of job stress such as, burnout, job satisfaction, turnover intention, organizational commitment, and job pressure (Akther and Others, 2017). The findings of the study also showed that there is no statistically significant difference in the level of work stress by demographic factors (age, gender, status, education qualification, job pessimism) but organizational factors have significant relationship with work stress level at work.

Job stress is considered rising and has become challenge for the employer as it increases high level stress that results in low productivity, increased absenteeism and collection to other employee problems like alcoholism, drug abuse, hypertension and host of cardiovascular problems (Ajayi, (2018). This study recommended that the employer should proactively minimize stress by providing adequate administrative support to employees; Optimize work load, effectively manage customer expectations, minimize relationship and role conflict, deploy adequate reward system and provide adequate training and counseling to employees in order to improve their job performance and job satisfaction.

In banking sector, there is already a certain level of stress on the employees work life and then encounter even more stress arising from the work pressure that bank employees face on the job. Many employees cannot cope with such rapid changes taking place in the jobs due to role conflict, service for customer, contribution, rapid technological change, lack of customer response etc. It is also found from the study that long time working hours, role of conflict and political pressure there is high degree of occupational work stress amongst the private and public sector bank employees (Kishori \& Vinothini, 2016). Study also found the significant factors that cause stress and negatively affect the performance of bank employees (Appendix 1 for details). The factors are increased workload, lower salaries, unreachable target, centralized management, customer dealings, technological problem, lack of acknowledgement, longer time frames. This study suggests that the banks should concentrate on these vital issues through congenial work environment and revision of compensation, technology system, service delivery system, and time management (Islam, and Others, 2014).The occupational stress level in the banking sector also involves with gender, type of bank, role, personal morals, high job-demands, low level of decision-making (Mannocci and Others 2018). However, study reveals that job stress has also a significant positive relationship with the independent variables, role conflict, work overload and work family conflict and 
has no relationship with role ambiguity (Rizwan and Others 2014). Hence, this study aims to identify the relationships between the stress factors and the turnover intensions of the private sector banks in Bangladesh (Appendix 2).

\section{Research Methods}

This purpose of this study was to identify the stress factors and its impact on turnover intension of private bank employees in Bangladesh. Both primary and secondary data were used to conduct this study. Primary data were collected from the bank employees of private banks in Bangladesh and the secondary data were collected from the books, magazines, and journals.

\subsection{Demographic Information of the Respondents}

This study conducted study on 206 readymade private bank employees in Bangladesh. Among the respondents, $63.60 \%$ of the respondents were male and $36.40 \%$ were female (Table 1).

Table 1. Gender Distribution of the Respondents

\begin{tabular}{lcccc}
\hline Gender & Frequency & Percent & Valid Percent & Cumulative Percent \\
\hline Male & 131 & 63.6 & 63.6 & 63.6 \\
Female & 75 & 36.4 & 36.4 & 100.0 \\
Total & 206 & 100.0 & 100.0 & \\
\hline
\end{tabular}

The respondent bank employees mostly (34\%) were at the age of 26-31 years followed by 32-37 years (29.60\%), $38-43$ years (16\%), 20-25 years $(13.10 \%)$, and above 44 years $(7.30 \%)$ (Table 2$)$.

Table 2. Age of the Respondents

\begin{tabular}{lcccc}
\hline Age in Years & Frequency & Percent & Valid Percent & Cumulative Percent \\
\hline 20 to 25 & 27 & 13.1 & 13.1 & 13.1 \\
26 to 31 & 70 & 34.0 & 34.0 & 47.1 \\
32 to 37 & 61 & 29.6 & 29.6 & 76.7 \\
38 to 43 & 33 & 16.0 & 16.0 & 92.7 \\
44 and above & 15 & 7.3 & 7.3 & 100.0 \\
Total & 206 & 100.0 & 100.0 & \\
\hline
\end{tabular}

Most of the employees under study are with 1-5 years of experience followed by 6-11 years, 12-17 years, 17-22 years, and above 22 years (Table 3 ).

Table 3. Experience of the Respondents

\begin{tabular}{lcccc}
\hline Experience in Years & Frequency & Percent & Valid Percent & Cumulative Percent \\
\hline 1 to 5 years & 93 & 45.1 & 45.1 & 45.1 \\
6 to 11 years & 61 & 29.6 & 29.6 & 74.8 \\
12 to 17 years & 37 & 18.0 & 18.0 & 92.7 \\
17 to 22 years & 13 & 6.3 & 6.3 & 99.0 \\
Above 22 years & 2 & 1.0 & 1.0 & 100.0 \\
Total & 206 & 100.0 & 100.0 & \\
\hline
\end{tabular}

\subsection{Sample Design and Determination of Sample Size}

According to the research findings presented at a workshop at the BIBM, there were a total of 90,265 employees in the banks in 2016, but in the following year their number came down to $81,245^{1}$. Hence, the sample size of this study was determined by using the following formula suggested by Yamane (1967.

\footnotetext{
${ }^{l}$ https://www.dhakatribune.com/business/banks/2018/05/25/2017-saw-5-470-employees-terminated-from-25-ban ks
} 


$$
n=\frac{N}{1+N(e)^{2}}
$$

Where, $n$ is the sample size, $N$ is the population size, and $e$ is the level of precision. For this study, level of precision is presumed as 0.07 and the population size is ninety thousand two hundred sixty five. Putting these values in the above equation, the required number of sample size becomes approximately 204. This study interviewed 206private bank employees from 10 banks under study. This figure is well above the critical sample size of 204 for employing multivariate analysis (Hair et al., 1998).

\subsection{Questionnaire Design}

The questionnaires of this study were developed through literature review. Responses to all the statements in the questionnaire were measured on a five-point scale ranging from 1 to 5 with 1 indicating strongly disagree and 5 indicating strongly agree. One of the relative advantages of using this scale is its suitability for the applications of multifarious statistical tools used in marketing and social research study (Malhotra, 1999). The collected data were statistically processed subsequently to get the useful information. The reliability statistics show that the internal consistency of the questionnaire is under the acceptable limit (Nunnally, 1978). The Cronbach's Alpha was identified as 0.712 of 22 items in the questionnaire which are at the acceptable level.

\subsection{Data Collection \& Analysis}

Data were collected from both primary and secondary sources. Primary data were used for the purpose of analyzing the effect of work stress on the performance of readymade garment workers in Bangladesh. The survey was conducted among the 206 private bank employees from 10 banks of Bangladesh. The survey was conducted in 2019. The interviewers were properly trained on the items included in the questionnaire for data collection before commencing the interview. Along with descriptive statistics ${ }^{2}$, inferential statistical ${ }^{3}$ techniques such as, Factor Analysis and Multiple Regression Analysis were used to analyze the data. A Principal Component Analysis (PCA) with an Orthogonal Rotation (Varimax) ${ }^{4}$ using the SPSS (Statistical Package for Social Sciences) was performed on the survey data. Multiple Regression Analysis ${ }^{5}$ such as, Multiple Regression was conducted by using SPSS to identify the relationships between the dependent and independent variables and the significant factors.

The execution of this study took a lot of time and effort to prepare this research paper. Specially, the survey section was very difficult to execute. The private bank employees are very busy people and with close deadlines and massive workloads. It was also difficult to manage them to participate and respond to the survey.

\footnotetext{
${ }^{2}$ Descriptive statistics includes statistical procedures that we use to describe the population we are studying. The data could be collected from either a sample or a population, but the results help us organize and describe data. Descriptive statistics can only be used to describe the group that is being studying. That is, the results cannot be generalized to any larger group.

${ }^{3}$ Inferential statistics is concerned with making predictions or inferences about a population from observations and analyses of a sample. That is, we can take the results of an analysis using a sample and can generalize it to the larger population that the sample represents.

${ }^{4}$ Varimax rotation is an orthogonal rotation of the factor axes to maximize the variance of the squared loadings of a factor (column) on all the variables (rows) in a factor matrix, which has the effect of differentiating the original variables by extracted factor. Each factor will tend to have either large or small loadings of any particular variable. A varimax solution yields results which make it as easy as possible to identify each variable with a single factor. This is the most common rotation option.

${ }^{5}$ In statistics, regression analysis is a statistical process for estimating the relationships among variables. It includes many techniques for modeling and analyzing several variables, when the focus is on the relationship between a dependent variable and one or more independent variables. More specifically, regression analysis helps one understand how the typical value of the dependent variable (or 'Criterion Variable') changes when any one of the independent variables is varied, while the other independent variables are held fixed.
} 


\section{Results and Discussions}

This section of the study includes the analysis of the results of factor analysis and multiple regression analysis.

\subsection{Results of Factor Analysis}

Factor analysis show that all the communalities of the variables are very high indicating that the variables constitutes the stress factors that increases turnover intention among the private bank employees are related to each other (Table 4).

Table 4. Communalities of the Variables

\begin{tabular}{clc}
\hline Variables & Extraction \\
\hline 1. I am pressured to work long hours. & .656 \\
2. I have unachievable deadline & .728 \\
3. I really think about looking for a job at another company & .774 \\
4. I have to work very fast & .658 \\
5. I have to neglect some tasks because I have too much to do & .453 \\
6. I am unable to take sufficient breaks & .629 \\
7. My working time cannot be flexible & .538 \\
8. I am not given supportive feedback on the work I do & .693 \\
9. I cannot rely on my manager to help me out with a work problem & .653 \\
10. I am not supported through emotionally demanding work & .510 \\
11. Most of the systems and processes here do not support us getting our work done effective & .430 \\
12. My line manager does not encourage me at work & .653 \\
13. When changes are made at work, I am not clear how they will work out in practice & .484 \\
14. I am not clear what is expected to me at work. & .760 \\
15. I am not clear about the goals and objectives for my department & .733 \\
16. I don't know how to go about getting my job done & .475 \\
17. My workload is very high all the time & .616 \\
18. I sometimes do not understand what to do & .509 \\
19. Sometimes, I am unclear about my job responsibilities & .611 \\
20. My company demands very high from me all the time & .555 \\
21. I often think of changing my job & .819 \\
22. I will probably look for a new job in the next year & .800
\end{tabular}

Extraction Method: Principal Component Analysis.

This study identified four stress factors that increase the turnover tension among the private bank employees in Bangladesh. The factors are (i) long hours and fast work (ii) clearness of goals and objectives of work (iii) workload and change in mindset and (iv) flexibility at work. The data set explains $62.43 \%$ of the variance (Table 5). The most important stress factor is long hours and fast work $(38.35 \%)$ followed by clearness of goals and objectives of work (12.94\%), workload and change in mindset (6.67\%) and flexibility at work (4.47\%).

Table 5. Total Variance Explained

\begin{tabular}{lccc}
\hline & \multicolumn{3}{c}{ Initial Eigenvalues } \\
\cline { 2 - 4 } Factors & Total & \% of Variance & Cumulative \% \\
\hline 1.Long Hours and Fast Work & 8.437 & 38.351 & 38.351 \\
2. Clearness of Goals and Objectives of Work & 2.846 & 12.938 & 51.289 \\
3.Workload and Change in Mindset & 1.466 & 6.664 & 57.953 \\
4. Flexibility at Work & 0.984 & 4.474 & 62.427 \\
\hline
\end{tabular}

Extraction Method: Principal Component Analysis. 
The rotated factors analysis results show that the factors constituted with the variables have higher level of correlations between them (Table 6).The first factor named long hours and fast work is constituted with eight variables followed by clearness of goals and objectives of work with five variables, workload and change in mindset with four variables and flexibility at work with five variables.

Table 6. Rotated Components Matrixa

\begin{tabular}{lr}
\hline \multicolumn{1}{c}{ Variables } & \multicolumn{1}{c}{. } \\
\hline Factor 1 Long Hours and Fast Working & .799 \\
4. I have to work very fast & .670 \\
1. I am pressured to work long hours. & .658 \\
2. I have unachievable deadline & .587 \\
20. My company demands very high from me all the time & .541 \\
6. I am unable to take sufficient breaks & .531 \\
18. I sometimes do not understand what to do & .524 \\
19. Sometimes, I am unclear about my job responsibilities & \\
5. I have to neglect some tasks because I have too much to do &
\end{tabular}

Factor 2 Clearness of Goals and Objectives of Work

14. I am not clear what is expected of me at work.

15. I am not clear about the goals and objectives for my department $\quad .802$

13. When changes are made at work, I am not clear how they will work out in practice $\quad .665$

16. I don't know how to go about getting my job done $\quad .604$

12. My line manager does not encourage me at work $\quad .585$

Factor 3 Workload and Change in Mindset

22. I will probably look for a new job in the next year $\quad .766$

3. I really think about looking for a job at another company $\quad .739$

$\begin{array}{ll}\text { 21. I often think of changing my job } & .726\end{array}$

17. My workload is very high all the time $\quad .612$

Factor 4 Flexibility at Work

7. My working time cannot be flexible $\quad .718$

10. I am not supported through emotionally demanding work $\quad .686$

8. I am not given supportive feedback on the work I do $\quad .651$

9. I cannot rely on my manager to help me out with a work problem $\quad .591$

11. Most of the systems and processes here do not support us getting our work done effective 495

Extraction Method: Principal Component Analysis.

Rotation Method: Varimax with Kaiser Normalization.

a. Rotation converged in 7 iterations.

\subsection{Results of Regression Analysis}

Regression results show that the correlation is 0.758 and the $\mathrm{R}$ square of the model is 0.575 which is in the acceptable limit (Table 7).

Table 7. Model Summary ${ }^{\mathrm{b}}$

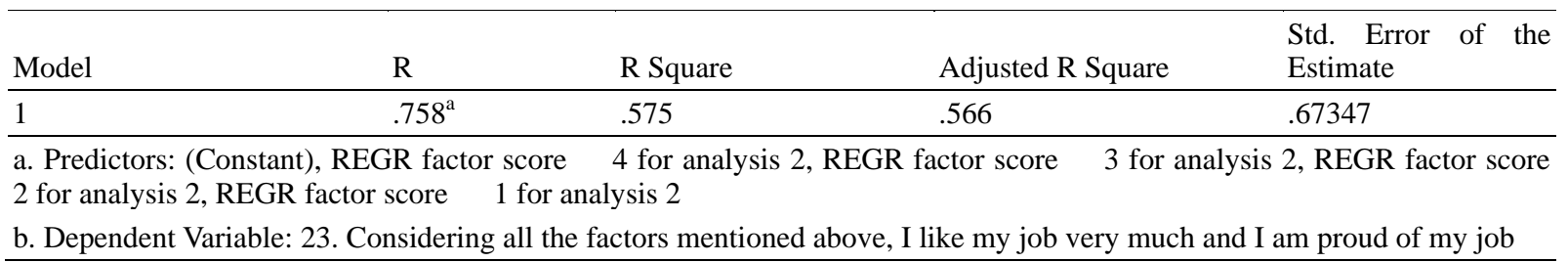

ANOVA shows that all the factors are significantly related to the overall turnover intension of the private bank employees in Bangladesh (Table 8). 
Table 8. ANOVA ${ }^{\mathrm{b}}$

\begin{tabular}{|c|c|c|c|c|c|}
\hline Model & Sum of Squares & $\mathrm{df}$ & Mean Square & $\mathrm{F}$ & Sig. \\
\hline Regression & 119.557 & 4 & 29.889 & 65.900 & $.000^{\mathrm{a}}$ \\
\hline Residual & 88.443 & 195 & .454 & & \\
\hline Total & 208.000 & 199 & & & \\
\hline
\end{tabular}

a. Predictors: (Constant), REGR factor score 4 for analysis 2, REGR factor score 3 for analysis 2, REGR factor score 2 for analysis 2, REGR factor score 1 for analysis 2

b. Dependent Variable: 23. Considering all the factors mentioned above, I like my job very much and I am proud of my job

Individual factor relationship with the overall turnover intension of the private bank employees in Bangladesh shows that all the factors individually significantly related to the overall turnover intension of the employees (Table 9).

Table 9. Coefficients ${ }^{\mathrm{a}}$

\begin{tabular}{|c|c|c|c|c|c|}
\hline \multirow[t]{2}{*}{ Factors } & \multicolumn{2}{|c|}{ Unstandardized Coefficients } & \multirow{2}{*}{$\begin{array}{c}\begin{array}{c}\text { Standardized } \\
\text { Coefficients }\end{array} \\
\text { Beta }\end{array}$} & \multirow[b]{2}{*}{$\mathrm{t}$} & \multirow[b]{2}{*}{ Sig. } \\
\hline & $\mathrm{B}$ & Std. Error & & & \\
\hline (Constant) & 3.200 & .048 & & 67.197 & .000 \\
\hline 1. Long Hours and Fast Work & -.187 & .048 & -.182 & -3.908 & .000 \\
\hline 2. Clearness of Goals and Objectives of Work & .262 & .048 & .256 & 5.490 & .000 \\
\hline 3. Workload and Change in Mindset & -.631 & .048 & -.618 & -13.227 & .000 \\
\hline 4. Flexibility at Work & .314 & .048 & .307 & 6.575 & .000 \\
\hline
\end{tabular}

\section{Conclusions and Recommendations}

The results of factor analysis show that the communalities of the variables are very high demonstrating that the relationships among the variables are high. Analysis also identified four stress factors that increase the turnover tension among the private bank employees in Bangladesh such as, long hours and fast work, clearness of goals and objectives of work, workload and change in mindset and flexibility at work. Analysis also shows that all the factors are significantly related to the overall turnover intension of the private bank employees in Bangladesh. Individually factors are also significantly related to the turnover intension of the private bank employees in Bangladesh. Four stress factors that highly increase the turnover intention among the private bank employees such as, long hours and fast work, clearness of goals and objectives of work, workload and change in mindset and flexibility at work are detected by this analysis. The study also identified the significant mutual relationship among the variables. Hence, recommendations can be as follows. (i) If these stress factors are properly addressed by the policymakers of the private commercial banks there will be a positive change in the turnover intension of the bank employees in Bangladesh (ii) If the variables are properly checked and kept to a desirable level, the turnover intention may drop significantly. However, there is an ample scope to conduct further study on this topic and there might have different factors related to stress of the bank employees in Bangladesh.

\section{Implications of the Study}

The stress factors identified here are evident to have significant impact on the turnover intention of the private bank employees. The top management or the administration of private banks in banking industry can use the result of this study to reduce the turnover intension level of the employees and maintaining the job stress level at minimum level. It will also help the Bangladeshi researchers to work further on this important topic and identify more factors related to job stress and job turnover intention of private bank employees in Bangladesh.

\section{References}

Ajayi, S. (2018). Effect of Stress on Employee Performance and Job Satisfaction: A Case Study of Nigerian Banking Industry. https://doi.org/10.2139/ssrn.3160620

Akther, S., Akter, S., \& Uddin, M. K. (2017). Factors Influencing Job Stress in Privatized Banks of Bangladesh. Global Management Review, 11(1), 1-17.

Das, A. C. (2016). Causes and effects of stress among working women in banking sector, Bangladesh. Mediscope, 3(1), 1-7. https://doi.org/10.3329/mediscope.v3i1.29729 
Giorgi, G., Arcangeli, G., Perminiene, M., Lorini, C., Ariza-Montes, A., Fiz-Perez, J., \& Mucci, N. (2017). Work-related stress in the banking sector: A review of incidence, correlated factors, and major consequences. Frontiers in psychology, 8, 2166. https://doi.org/10.3389/fpsyg.2017.02166

Hair, J. F., Anderson, R. E., Tatham, R. L., \& William, C. (1998). Black (1998), Multivariate data analysis.

Kishori, B., \& Vinothini, B. (2016). A Study on Work Stress Among Bank Employees in State Bank of India with Reference to Tiruchirappalli. IJIRST-International Journal for Innovative Research in Science \& Technology, 2, 12.

Malhotra, N. K., Peterson, M., \& Kleiser, S. B. (1999). Marketing research: A state-of-the-art review and directions for the twenty-first century. Journal of the academy of marketing science, 27(2), 160-183. https://doi.org/10.1177/0092070399272004

Mannocci, A., Marchini, L., Scognamiglio, A., Sinopoli, A., De Sio, S., Sernia, S., \& La Torre, G. (2018). Are bank employees stressed? Job perception and positivity in the banking sector: An Italian observational study. International Journal of Environmental Research and Public Health, 15(4), 707. https://doi.org/10.3390/ijerph15040707

Nunnally, J. (1978). Psychometric methods.

Rizwan, M., Raza, M. A., Mateen, M. A., Tehseen, F., Farooq, M. S., Javed, A., \& Javed, S. (2014). Investigating the causes of job stress: a study on banking sector of Bahawalpur, Pakistan. International Journal of Learning and Development, 4(2), 227. https://doi.org/10.5296/ijld.v4i2.6099

Appendix 1. Job Stress Variables

\begin{tabular}{|c|c|c|c|c|c|c|c|}
\hline Authors/Year & $\begin{array}{l}\text { Work } \\
\text { Environment }\end{array}$ & $\begin{array}{l}\text { Work } \\
\text { load }\end{array}$ & $\begin{array}{l}\text { Role } \\
\text { Conflict }\end{array}$ & $\begin{array}{l}\text { Role } \\
\text { Ambiguit } \\
\mathrm{y}\end{array}$ & $\begin{array}{l}\text { Work-family } \\
\text { life conflict }\end{array}$ & $\begin{array}{l}\text { Organizational } \\
\text { commitment }\end{array}$ & $\begin{array}{l}\text { Emotional } \\
\text { Stress }\end{array}$ \\
\hline $\begin{array}{l}\text { (Mosadeghrad, } \\
\text { 2013) }\end{array}$ & $\sqrt{ }$ & $\sqrt{ }$ & $\sqrt{ }$ & $\sqrt{1}$ & $\sqrt{ }$ & $\sqrt{ }$ & \\
\hline $\begin{array}{l}\text { Nasrin } \\
\text { Damiri, 2012) }\end{array}$ & $\sqrt{ }$ & & $\sqrt{ }$ & $\sqrt{ }$ & $\sqrt{ }$ & $\sqrt{ }$ & \\
\hline $\begin{array}{l}\text { (Hendrix, } \\
\text { Spencer, \& } \\
\text { Gibson, 1994) }\end{array}$ & & $\sqrt{ }$ & $\sqrt{ }$ & & $\sqrt{ }$ & & $\sqrt{ }$ \\
\hline (Perera, 2016) & $\sqrt{ }$ & $\sqrt{ }$ & $\sqrt{ }$ & $\sqrt{ }$ & & $\sqrt{ }$ & $\sqrt{ }$ \\
\hline $\begin{array}{l}\text { (Kumari, Joshi, } \\
\text { \& Pandey, 2016) }\end{array}$ & & $\sqrt{ }$ & $\sqrt{ }$ & $\sqrt{ }$ & & & \\
\hline $\begin{array}{l}\text { (Tsutsumi \& } \\
\text { Kayaba, 2001) }\end{array}$ & $\sqrt{ }$ & $\sqrt{ }$ & & & & $\sqrt{ }$ & $\sqrt{ }$ \\
\hline $\begin{array}{l}\text { (Chang, } \\
\text { Hancock, } \\
\text { Johnson, Daly, } \\
\text { \& Jackso, 2005) }\end{array}$ & $\sqrt{ }$ & $\sqrt{ }$ & $\sqrt{ }$ & $\sqrt{ }$ & $\sqrt{ }$ & & $\sqrt{ }$ \\
\hline $\begin{array}{l}\text { (Carayon, } \\
\text { Smith, \& Haim, } \\
\text { 1999) }\end{array}$ & $\sqrt{ }$ & $\sqrt{ }$ & & & & & $\sqrt{ }$ \\
\hline $\begin{array}{l}\text { (Lindforsa, } \\
\text { Eintreib, \& } \\
\text { Alexandersona, } \\
\text { 2009) }\end{array}$ & $\sqrt{ }$ & $\sqrt{ }$ & $\sqrt{ }$ & & $\sqrt{ }$ & & $\sqrt{ }$ \\
\hline $\begin{array}{l}\text { (Kwon, Ja, Lee, } \\
\& \quad \text { Seung-Hee, } \\
2012 \text { ) }\end{array}$ & & $\sqrt{ }$ & $\sqrt{ }$ & $\sqrt{ }$ & & & $\sqrt{ }$ \\
\hline
\end{tabular}


Appendix 2. Turnover Intention Variables

\begin{tabular}{|c|c|c|c|c|c|c|c|c|c|c|c|}
\hline Author(s) & $\begin{array}{l}\text { Job } \\
\text { Satisf } \\
\text { actio } \\
\mathrm{n}\end{array}$ & $\begin{array}{l}\text { Job } \\
\text { stre } \\
\text { ss }\end{array}$ & $\begin{array}{l}\text { Organizati } \\
\text { onal } \\
\text { Commitm } \\
\text { ent }\end{array}$ & Pay & $\begin{array}{l}\text { Promo } \\
\text { tion }\end{array}$ & $\begin{array}{l}\text { Career } \\
\text { develop } \\
\text { ment }\end{array}$ & $\begin{array}{l}\text { Cowork } \\
\text { er } \\
\text { relation } \\
\text { ship }\end{array}$ & $\begin{array}{l}\text { Perfor } \\
\text { mance } \\
\text { Apprai } \\
\text { sal }\end{array}$ & $\begin{array}{l}\text { Work } \\
\text { environ } \\
\text { ment }\end{array}$ & $\begin{array}{l}\text { Organiza } \\
\text { tional } \\
\text { Culture }\end{array}$ & $\begin{array}{l}\text { Organiza } \\
\text { tional } \\
\text { Justice }\end{array}$ \\
\hline $\begin{array}{l}\text { (Hossain et } \\
\text { al., 2017) } \\
\end{array}$ & & & & $\sqrt{ }$ & & $\sqrt{ }$ & & $\sqrt{ }$ & $\sqrt{ }$ & & \\
\hline $\begin{array}{l}\text { (Alias et al., } \\
\text { 2018) }\end{array}$ & $\sqrt{ }$ & & $\sqrt{ }$ & & & & $\sqrt{ }$ & & & & \\
\hline $\begin{array}{l}\text { (Lee, C. C., } \\
\text { Huang, S. } \\
\text { H., \& Zhao, } \\
\text { C. Y., 2012). }\end{array}$ & $\sqrt{ }$ & & $\sqrt{ }$ & & & & $\sqrt{ }$ & & & & \\
\hline $\begin{array}{l}\text { (AK, B., } \\
2018)\end{array}$ & $\sqrt{ }$ & $\sqrt{ }$ & $\sqrt{ }$ & $\sqrt{ }$ & $\sqrt{ }$ & & & & $\sqrt{ }$ & $\sqrt{ }$ & $\sqrt{ }$ \\
\hline $\begin{array}{l}\text { (Zhang, Y., } \\
\text { 2016). }\end{array}$ & & & & $\sqrt{ }$ & $\sqrt{ }$ & $\sqrt{ }$ & $\sqrt{ }$ & & & $\sqrt{ }$ & $\sqrt{ }$ \\
\hline $\begin{array}{l}\text { (Hassan, R., } \\
\text { 2014) }\end{array}$ & $\sqrt{ }$ & & $\sqrt{ }$ & $\sqrt{ }$ & $\sqrt{ }$ & & & & & & \\
\hline $\begin{array}{l}\text { (Chen et al., } \\
2014)\end{array}$ & $\sqrt{ }$ & $\sqrt{ }$ & $\sqrt{ }$ & $\sqrt{ }$ & & & & & & & \\
\hline
\end{tabular}

\section{Copyrights}

Copyright for this article is retained by the author(s), with first publication rights granted to the journal.

This is an open-access article distributed under the terms and conditions of the Creative Commons Attribution license (http://creativecommons.org/licenses/by/4.0/). 